\title{
MAGYARORSZÁG GEOTERMIKUS FELMÉRÉSE A MAGYAR ENERGETIKAI ÉS KÖZMŰ-SZABÁLYOZÁSI HIVATAL GEOTERMIKUS PROJEKTJEI TÜKRÉBEN
}

\section{GEOTHERMAL SURVEY OF HUNGARY AS REGARDS OF THE HUNGARIAN ENERGY \& UTILITIES REGULATORY AGENCY GEOTHERMAL PROJECTS}

\author{
Tóth Anikó Nóra \\ PhD, egyetemi docens, Miskolci Egyetem Kőolaj és Földgáz Intézet Gázmérnöki Tanszék, a Környezettudományi Elnöki Bizottság \\ (KÖTEB) Energetika és Környezet Albizottságának tagja \\ toth.aniko@uni-miskolc.hu
}

\begin{abstract}
ÖSSZEFOGLALÁS
Köztudott, hogy Magyarország természeti adottságai igen kedvezőek a geotermikus energia hasznosítására. Az elvékonyodott $(\sim 25 \mathrm{~km})$ kéreg a Kárpát-medencében a kontinentális átlagnál nagyobb földi hőáramot és geotermikus gradienst eredményez. A jelenleg hasznosított hidrotermális rendszerek hőmérséklete általában a közvetlen hőhasznosítást teszi indokolttá. A geotermikus energia fütési és mezőgazdasági célú felhasználásában világviszonylatban is az élcsoportban vagyunk. Jóllehet az elmúlt időszakban jó néhány nagy léptékű geotermikus projekt indult, bármely beruházás indításának egyik sarkalatos alapkövetelménye egy megbízható, könynyen kezelhető geotermikus alapadatbázis. A Magyar Energetikai és Közmű-szabályozási Hivatal kezdeményezésére 2016-ban egy tanulmány készült Magyarország geotermikus atlasza címmel, amelyben a geotermikus potenciál felmérése és bemutatása szerepel az ország tizenkilenc megyéjére. A tanulmányban, amely alapvetően a Magyar Bányászati és Földtani Szolgálat (ez időben Magyar Bányászati és Földtani Hivatal és a Magyar Földtani és Geofizikai Intézet), valamint a Bányavagyon-hasznosító Nonprofit Kft. által szolgáltatott alapadatokra épült, 1622 regisztrált és működő geotermikus kút, valamint több mint 170 felhagyott meddő szénhidrogénkút paramétereit vizsgáltuk. A szükséges adatok összegyűjtése, rendszerezése és elemzése alapján az ország területére $30,50,70$ és $90^{\circ} \mathrm{C}$-os geoizoterma-térkép készült, amely bemutatja, hogy adott kőzethőmérséklet milyen mélységben várható. A tanulmány táblázatok, grafikonok és térképek segítségével összegzi és mutatja be mind a tizenkilenc megye geotermikus lehetőségeit.
\end{abstract}

\section{ABSTRACT}

Hungary's excellent geothermal potential is well-known. The Pannonian Basin, surrounded by the Carpathian Mountains, is an area where the Earth's crust is relatively thin $(\sim 25 \mathrm{~km})$. As a result, the terrestrial heat flow and geothermal gradient is higher there than the continental 
average. The hydrothermal systems currently being used in this region have a temperature and enthalpy which usually justifies direct heat utilization. Heating and agriculture are two of the main applications for geothermal energy in Hungary. One of the basic requirements for geothermal investment is a reliable geothermal base database, which was still lacking when several large-scale geothermal projects were recently launched. The Hungarian Energy and Public Utility Regulatory Authority requested in 2016 that a study be made to analyse and summarize the geothermal potential of each of the 19 counties in the country. The resulting study used information from the Hungarian Geological and Geophysical Institute, and consulted the geothermal databases of the Hungarian Office for Mining and Geology. These two sources yielded data for 1622 thermal wells. In addition, more than 170 abandoned hydrocarbon wells were also analyzed, as the Hungarian Mine Utilization Authority judged those wells to be suitable for geothermal use. To make it easier for the average user, isothermal maps of Hungary were created, showing the different depths at which a particular temperature was attained. Those temperatures were $30^{\circ} \mathrm{C}, 50^{\circ} \mathrm{C}, 70^{\circ} \mathrm{C}$, and $90^{\circ} \mathrm{C}$. In the course of assembling the necessary data into a national geothermal atlas, numerous smaller-scale charts and graphs and maps were also created.

Kulcsszavak: geotermikus adatbázis, termálkút, felhagyott szénhidrogénkút, nemzeti geotermikus atlasz

Keywords: geothermal database, thermal well, abandoned hydrocarbon well, national geothermal atlas

\section{GEOLÓGIAI HÁTTÉR}

A Pannon-medence Európa egyik pozitív geotermikus anomáliájú területe, ahol a hőáramsürüség átlagos értéke $90-100 \mathrm{~mW} / \mathrm{m}^{2}$, a geotermikus gradiens átlagos értéke $45-55^{\circ} \mathrm{C} / \mathrm{km}$ (Dövényi et al., 1983, 2002). Magyarországon két fő típusú geotermális tározó található. Az első típus az Alföld felső pannon többrétegü porózus üledéksoraiban található, mely egymás feletti agyagos és homokos rétegződésủ és alacsony hővezető képességü. Kiterjedése mintegy 40 $000 \mathrm{~km}^{2}$, vastagsága 100-300 m, mélysége 700-1800 m, hőmérséklete 60-90 ${ }^{\circ} \mathrm{C}$ közötti (Boldizsár, 1958, 1967). A tároló pórusvíztömege gyakorlatilag hidrosztatikus egyensúlyi állapotban van. Ez egy egységes, $40000 \mathrm{~km}^{2}$-es tároló létezését sugallhatná, de ezt a váltakozóan homokos-agyagos rétegződés megbontja (Bobok-Tóth, 2010).

A második típus az üledékes Pannon-medence rétegsorai alatti, kettős porozitású, repedezett paleozóos-mezozóos kristályos kőzetekben található átlagosan 2000 m-es vagy annál nagyobb mélységben. Ezek $100-120{ }^{\circ} \mathrm{C}$-ot is meghaladó hömérsékletủek, ezáltal kedvezö feltételeket teremthetnek közepes entalpiájú geotermikus rendszerek kombinált hö- és áramtermelésére (Tóth, 2015). 


\section{GEOTERMIKUS ENERGIA TERMELÉSE HAZÁNKBAN}

Magyarországon a $30{ }^{\circ} \mathrm{C}$-nál melegebb források és kutak vizét nevezik hévíznek. Hévíztermelésünk a felső pannon homokos, homokköves, porózus tárolóiból (1. típus) és a mélykarszt repedezett karbonátos rezervoárjaiból (2. típus) történik. Az elmúlt ötven évben a kitermelt termálvíz mennyisége változó, ugyanakkor folyamatosan növekvő tendenciát mutat. Magyarországon a geotermikus energia termelése a hévizek energiatartalmának hasznosításán alapul. Ehhez járul a felszín alatti sekély, 0-200 m közötti mélységtartományba eső rétegek energiatartalmának víztermelés nélküli, talajszondák és hőszivattyúk révén történő felszínre hozatala. A hévízkutak száma az országban 1622 (forrás: a 13.2. Kútkataszteri kiadványok, Magyarország hévizkútjai VII. kiegészitése javitásokkal, 2015). A Magyar Bányászati és Földtani Hivatal (2016) adatközlése alapján 2015-ben a kitermelt hévíz mennyisége 24,608 millió $\mathrm{m}^{3}$ /év. A termelt hőmennyiség 2509 TJ.

Az 1. táblázat szemlélteti Magyarország meglévő termálkútjainak jellemzőit (Tóth, 2016, 2017). Az első oszlopban $10{ }^{\circ} \mathrm{C}$-os intervallumonként a kútfejhőmérsékletet találjuk. A következő oszlopok az adott hőmérséklet-tartományhoz tartozó kutak számát tartalmazzák a hasznosítás módja szerint. Itt a rövidítések jelentése: F - fürdők, M - mezőgazdaság, K - kommunális, I - ipari, T - többcélú felhasználás. Végül a $\Sigma$ az adott hőmérséklet-intervallumba tartozó kutak számának összegét jelöli.

1. táblázat. Hévízkútjaink száma a kútfejhőmérséklet és a felhasználás függvényében (Tóth, 2016)

\begin{tabular}{|r|r|r|r|r|r|c|}
\hline $\mathbf{T}_{\text {kútfej }}$ & $\mathbf{F}$ & $\mathbf{M}$ & $\mathbf{K}$ & $\mathbf{I}$ & $\mathbf{T}$ & $\boldsymbol{\Sigma}$ \\
\hline $\mathbf{3 0}-\mathbf{4 0}$ & 250 & 278 & 2 & 102 & 67 & 699 \\
\hline $\mathbf{4 0}-\mathbf{5 0}$ & 213 & 29 & 32 & 24 & 58 & 356 \\
\hline $\mathbf{5 0 - 6 0}$ & 98 & 51 & 4 & 22 & 26 & 201 \\
\hline $\mathbf{6 0}-\mathbf{7 0}$ & 66 & 39 & 17 & 12 & 41 & 175 \\
\hline $\mathbf{7 0}-\mathbf{8 0}$ & 14 & 25 & 8 & 9 & 25 & 81 \\
\hline $\mathbf{8 0}-\mathbf{9 0}$ & 6 & 37 & 3 & 6 & 9 & 61 \\
\hline $\mathbf{9 0}-\mathbf{1 0 0}$ & 5 & 33 & 5 & 1 & 1 & 45 \\
\hline $\mathbf{1 0 0}<$ & & 1 & 2 & & 1 & 4 \\
\hline $\boldsymbol{\Sigma}$ & 652 & 493 & 73 & 176 & 228 & 1622 \\
\hline
\end{tabular}

A 2. táblázat a geotermikus alapú közvetlen hőhasznosítás magyarországi megoszlását mutatja a Magyar Bányászati és Földtani Hivatal, Magyar Földtani és 
Geofizikai Intézet, Országos Vízügyi Hivatal, Központi Statisztikai Hivatal, PannErgy, European Geothermal Council, International Geothermal Association és a World Geothermal Congress 1015 adatai, kiadványai, tanulmányai alapján szintetizálva.

2. táblázat. Geotermikus alapú közvetlen höhasznosítás 2015-ben (Tóth, 2016)

\begin{tabular}{|l|c|}
\hline Épületek fütése & $33,02 \mathrm{MW}_{\mathrm{t}}$ \\
Távfütés & $186,56 \mathrm{MW}_{\mathrm{t}}$ \\
Üvegházak fütése & $271,00 \mathrm{MW}_{\mathrm{t}}$ \\
Haltenyésztés & $6,00 \mathrm{MW}_{\mathrm{t}}$ \\
Állattenyésztés & $4,00 \mathrm{MW}_{\mathrm{t}}$ \\
Mezőgazdasági szárítás & $25,00 \mathrm{MW}_{\mathrm{t}}$ \\
Ipari célok & $19,00 \mathrm{MW}_{\mathrm{t}}$ \\
\hline Balneológia (gyógyvíz) & $352,00 \mathrm{MW}_{\mathrm{t}}$ \\
\hline Földhőszivattyúk & $42,00 \mathrm{MW}_{\mathrm{t}}$ \\
\hline Összesen & $\mathbf{9 3 8 , 5 8} \mathbf{M W}_{\mathrm{t}}$ \\
\hline
\end{tabular}

\section{GEOTERMIKUS ATLASZ}

Az elmúlt öt-nyolc évben Magyarország geotermikus természeti adottságairól a nyomtatott és elektronikus médiában számos, sokszor igen általános és elnagyolt, nemritkán ellentmondásos, némelykor túlzottan derúlátó vagy éppen túlzottan lebecsülő cikk, kiadvány jelent meg. Ugyanakkor egy-egy kiemelt régióra több, nagyon részletes tanulmány is készült, amelyek a szükebb körü szakmai érdeklődők számára érthetők, és sok esetben az interneten könnyen el is érhetők. A Magyar Energetikai és Közmü-szabályozási Hivatal (MEKH) kezdeményezésére készült tanulmány célja a rendelkezésre álló geotermikus erőforrásokról való átfogó és könnyen érthető, széles körü tájékoztatás, amely egyben elösegítheti a potenciális hazai és külföldi befektetők döntését. A 2016ban készült és 2017-ben nyomtatásban, valamint elektronikusan szabadon letölthetö formátumban megjelent geotermikus atlasz ezt az igényt kívánta kielégíteni, a geotermikus energia, potenciál, gradiens, földi hőáram fogalmainak tisztázásával és Magyarország teljes területére, megyénkénti bontásban történt vizuális megjelenítésével (Tóth, 2016). 


\section{GEOIZOTERMA-TÉRKÉPEK}

A geotermikus gradiens értékét sok véletlenszerü hatás befolyásolja. Regionális értékelés és szemléltetés céljára alkalmasabbnak tủnik a mélységi izotermák rendszere. Ez esetünkben azt jelenti, hogy valamely adott hőmérséklet előfordulásához tartozó mélység izovonalait ábrázoljuk. Magyarország területén a pannon üledéksorokat több mint tízezer fúrás harántolja. Mintegy ezer bányászati célból mélyített földtani kutató fúrás hatolt be a miocén és régebbi rétegekbe. A kapott hőmérsékletértékek térbeli változásából rajzolhatók ki az izotermák. A geoizoterma-térképek egy adott hőmérséklet mélység menti szintfelületeit rajzolják ki. Minél közelebb esik egy geoizoterma a felszínhez, annál magasabb a geotermikus gradiens értéke. A geotermikus térképek megrajzolásához egyes megyékben (például Békés, Csongrád) a nagyszámú hazai müködő termálkút vagy éppen szénhidrogénfúrás adatai jó kiinduló alapul szolgáltak. Ezzel ellentétben, más megyékben (Komárom, Fejér, Nógrád) a geotermikus jellemzők pontos meghatározását korábban nem dokumentálták.

Annak érdekében, hogy megkönnyítsük a tájékozódást az átlagos felhasználó számára, öt különböző hőmérsékletre - 30, 50, 60, 70 és $90{ }^{\circ} \mathrm{C}$ - készítettünk izotermikus térképet Magyarország területére, amelyek bemutatják, hogy egy adott hőmérsékletérték milyen mélységekben érhető el. A hőmérsékletértékek

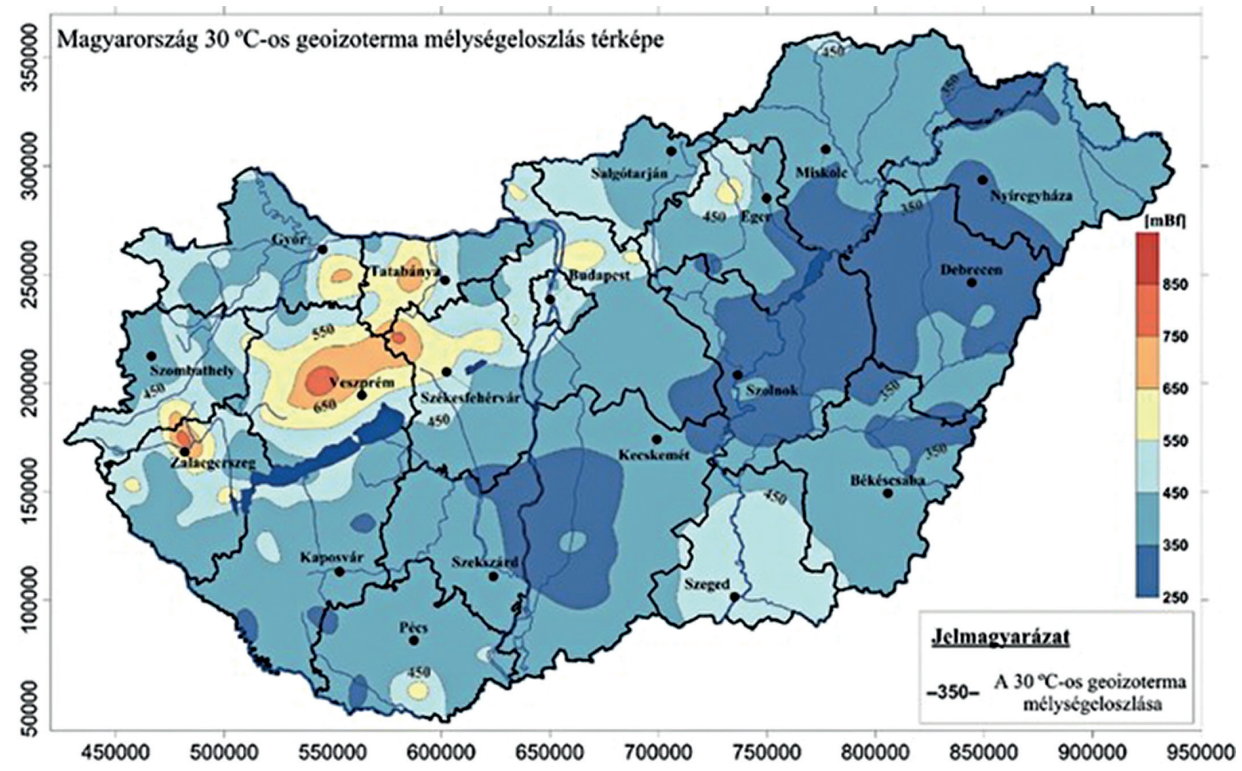

1. ábra. A $30^{\circ} \mathrm{C}$-os kőzethőmérséklet mélységeloszlása (mBf a Balti-tenger szintjétől mért magasságot jelenti) (Tóth, 2016) 
választását gyakorlati szempontok diktálták: $30^{\circ} \mathrm{C}$ a legalacsonyabb, mivel Magyarországon e hőmérsékletnél melegebb vizeket nevezzük hévizeknek, $90^{\circ} \mathrm{C}$ a legmagasabb, mivel a magyar termálkutak mindössze 3\%-ának vize melegebb $90{ }^{\circ} \mathrm{C}$-nál.

A $30^{\circ} \mathrm{C}$-os geoizoterma-térkép (1. ábra) mutatja, hogy ez a kőzethőmérséklet Magyarország területén a Bakony és a Bükk-fennsík kivételével már 400-500 m mélységben bárhol elérhető. Az ehhez közeli hőmérsékletű termálvizek elsősorban balneológiai célra használhatók, azonban hőszivattyúval kiegészítve sokrétü ipari hőszolgáltatásra is alkalmasak lehetnek.

Az $50{ }^{\circ} \mathrm{C}$-os geoizoterma-térkép (2. ábra) mutatja, hogy ez a kőzethőmérséklet Magyarország területén már 700-900 m mélységben bárhol elérhető szintén a Bakony, az Aggteleki-karszt és a Bükk-fennsík kivételével. Ez a hőmérséklet már alkalmas lehet akár lemezradiátoros fütési rendszerek energiaigényének kielégítésére. Mezőgazdasági célra, üvegházak, fóliasátrak, állattartó telepek fütésére közvetlenül használható, hőszivattyú segítségével nagyobb léptékủ távfütő rendszert is alapozhatunk $50{ }^{\circ} \mathrm{C}$-os forrásra.

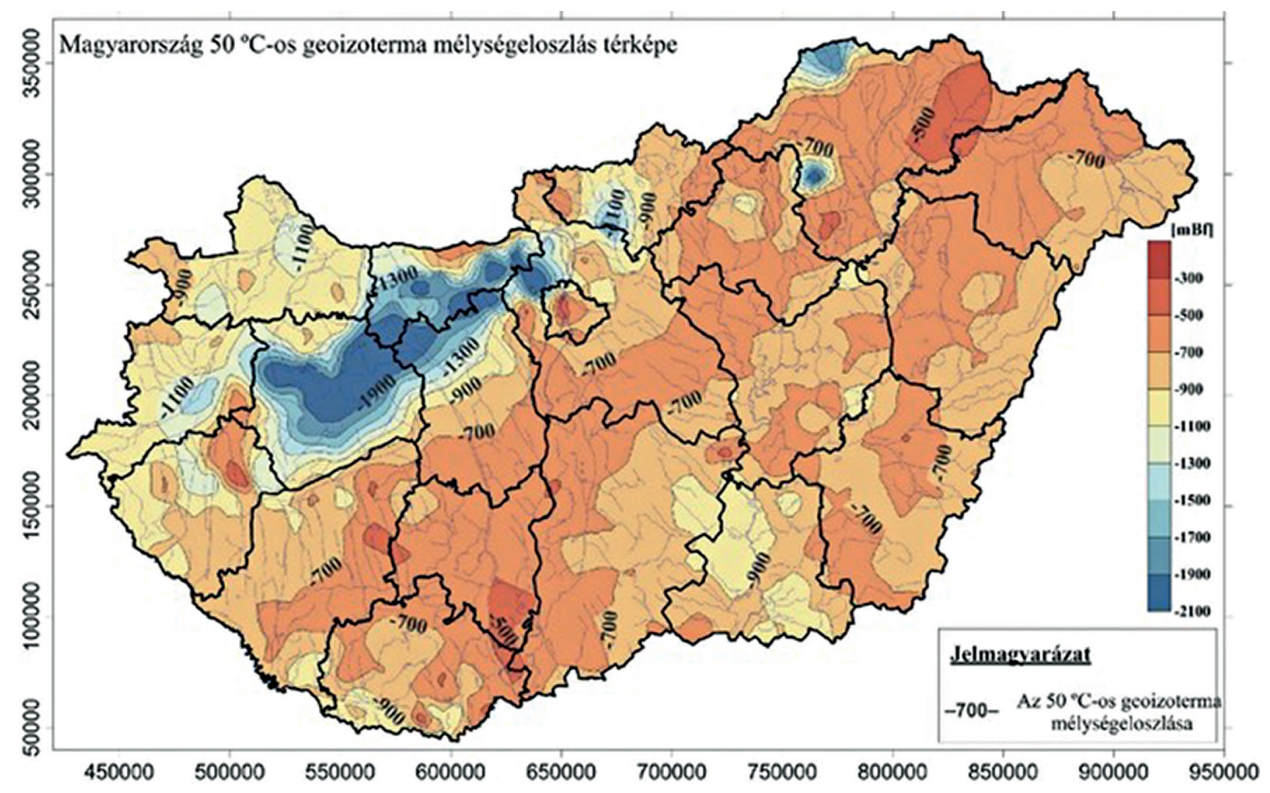

2. ábra. Az $50{ }^{\circ} \mathrm{C}$-os kőzethőmérséklet mélységeloszlása (Tóth, 2016)

A $70{ }^{\circ} \mathrm{C}$-os geoizoterma (3. ábra) rávilágít, hogy a Zempléni-hegység és a Tolnai-dombság területén 500-700 m-rel a felszín alatt található ez a hőmérséklet. Ez kiemelkedő geotermikus gradiensre utal. 


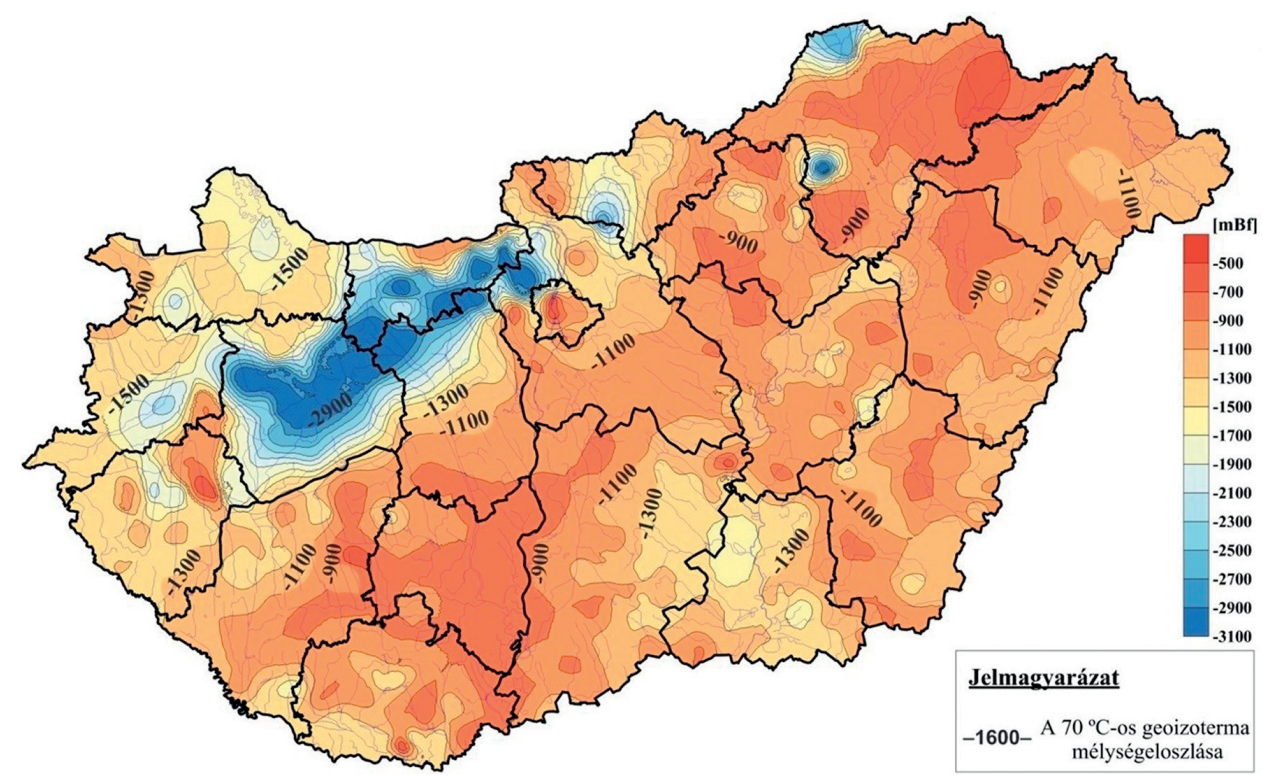

3. ábra. A $70^{\circ} \mathrm{C}$-os kőzethőmérséklet mélységeloszlása (Tóth, 2016)

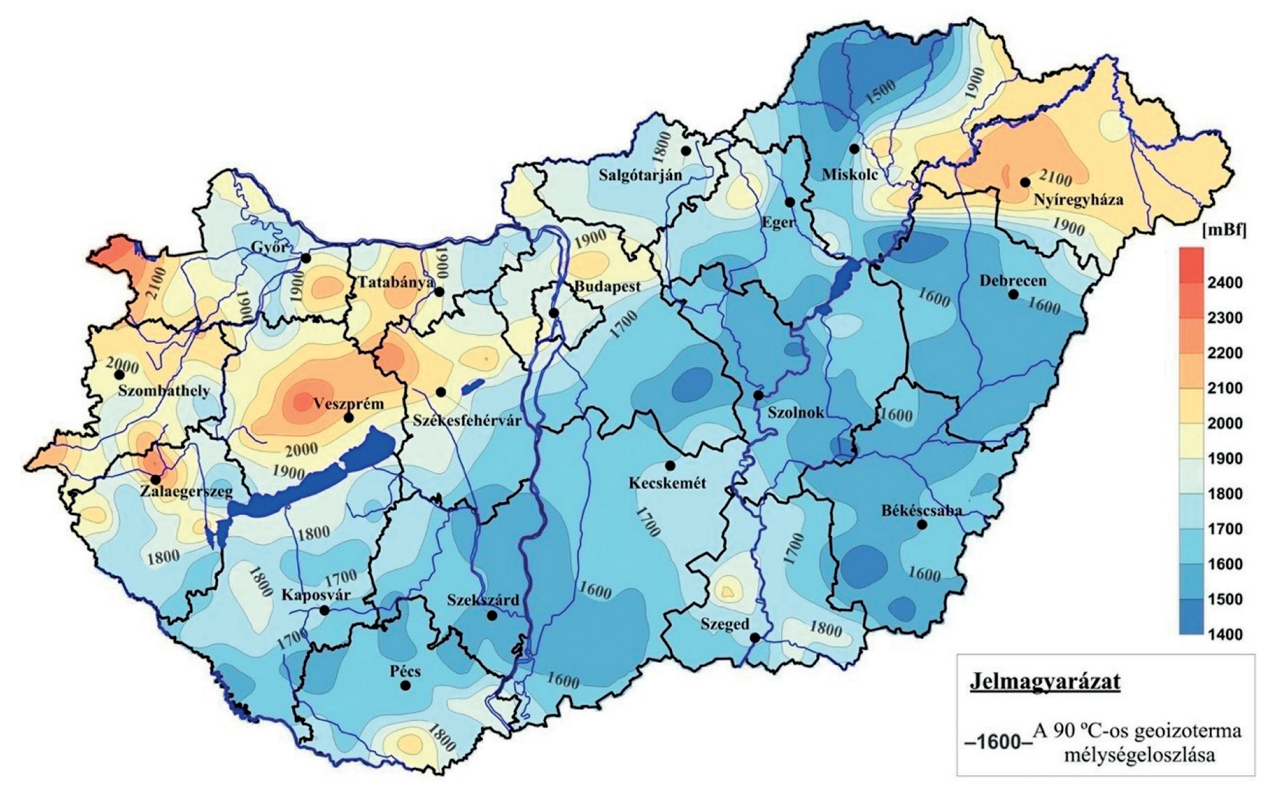

4. ábra. A $90^{\circ} \mathrm{C}$-os kőzethőmérséklet mélységeloszlása (Tóth, 2016) 
A $90{ }^{\circ} \mathrm{C}$-os geoizoterma (4. ábra) alakulása szerint ez a hőmérséklet az Alföld nagy területein 1600-1700 m mélységben jelenik meg, viszont meglepő anomália a Cserehát vidéke, ahol a $90{ }^{\circ} \mathrm{C}$ kőzethőmérséklet már 1400 m mélységben várható. A $90{ }^{\circ} \mathrm{C}$-os vagy magasabb hőmérsékletủ termálvízzel gyakorlatilag bármely ipari és lakossági hőigény kielégíthető.

Feltétlenül kiemelendő, hogy a hőmérséklet megfelelő értéke szükséges, de önmagában nem elegendő feltétele a geotermikus energia bármely hasznosításának. A rendszer teljesítményét a hőmérséklet mellett a kitermelt hévíz hozama határozza meg.

\section{GEOTERMIKUS LEHETŐSÉGEK MEGYÉNKÉNT}

Jóllehet Magyarország mind a tizenkilenc megyéjében vannak müködő geotermikus kutak, nagy eltérés mutatkozik mind a kutak száma, mind a kitermelt menynyiség és a víz hőmérséklete tekintetében. A korábban rendelkezésre álló publikus információk nem kielégítő volta miatt a Magyar Energiaügyi és Közüzemi Szabályozó Hatóság kérésére olyan adatbázis, majd atlasz készült, amely részletesen bemutatja és elemzi az egyes megyék geotermikus lehetőségeit a meglévő termálkutak, valamint a felhagyott, de geotermikus hasznositásra alkalmasnak ítélt szénhidrogénkutak tükrében. A szakhatóságok, hivatalok, intézetek, szakmai tanulmányok által szolgáltatott ismeretanyagra épülve, széles körü és összehangolt elemzés és összegezés után, táblázatos formába szerkesztve került bemutatásra a termálkutak, valamint a felhagyott szénhidrogénkutak regisztrációs száma, a település neve, a kút pontos helye EOVX- és EOVY-koordinátákkal, a kút létesítésének éve, a kút mélysége és a kifolyóvíz hőmérséklete. A táblázatok mellett megyénként térképi megjelenítés is segíti a könnyebb eligazodást. Az 5. ábra a múködő termálkutak (bal oldali szám) és a felhagyott szénhidrogénkutak (/ után) számát szemlélteti.

A továbbiakban tanulságos részletezni két igen különböző, ugyanakkor a geotermikus potenciál, termálvíztermelés és -hasznosítás szempontjából reprezentáns megye, Csongrád és Borsod-Abaúj-Zemplén jellemzőit.

Köztudott, s az 5. ábrán bemutatott megyénkénti kútszámok alapján is látszik, hogy a legtöbb müködő termálkút Csongrád megyében van. A magyarázata egyszerủen az, hogy Csongrád megyének kiemelkedőek a geotermikus adottságai: a geotermikus gradiens $37-45^{\circ} \mathrm{C} / \mathrm{km}$, a földi höáram $90-106 \mathrm{~mW} / \mathrm{m}^{2}$ (Dövényi et al., 1983). A felső-pannon feküjére települt homokos-homokköves hévíztároló rétegek a legjobb geotermikus rezervoárjainkat képezik. A legrégebbi hévízkút 1927-ben lett mélyítve. A megye területének geológiai megkutatottságát óriási mértékben növelte a kőolajipar által 1944-től folyamatosan létesített nagyszámú olaj- és földgáztermelö kút. Az olajipar által létesített, de meddőnek bizonyult kutak egy részét már átalakították hévíztermelő kúttá. Csongrád megyében a hévízkataszterben szereplő 


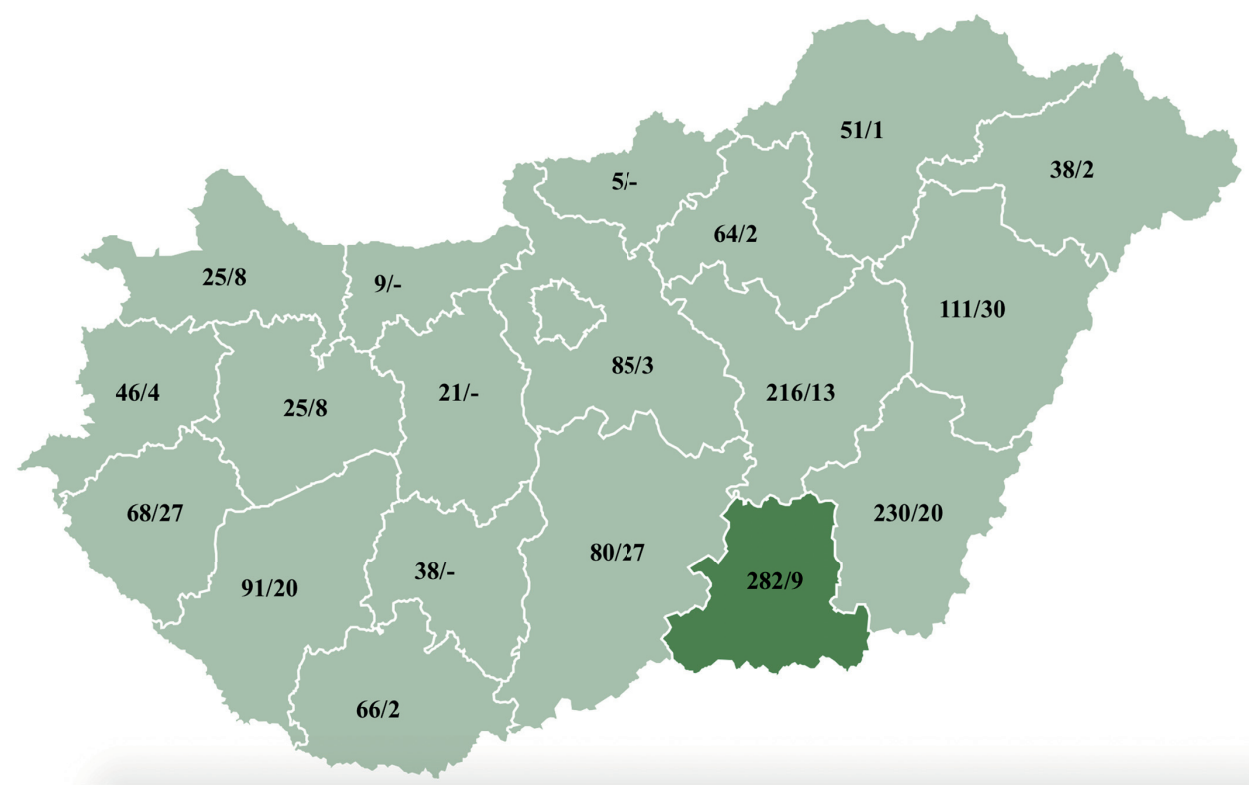

5. ábra. Működő termálkutak és felhagyott szénhidrogénkutak száma megyénként (Tóth, 2016)

termálkutak száma 282. Ez az országban található termálkutak számának ötöde. Ezek közül kiemelkedő Szeged és vonzáskörzete, ahol 90 kút található. Szentesen 34 kút szolgáltat hévizet. Hódmezővásárhelyen 21 kút vesz részt a hévízellátásban. A megye kútjai közül 122 -nek $60-90{ }^{\circ} \mathrm{C}$ közötti a kifolyóvíz-hőmérséklete, 32 kút ad $90^{\circ} \mathrm{C}$-os vagy annál melegebb vizet. A kitermelt hévíz mennyisége éves szinten 25-30 millió $\mathrm{m}^{3}$ közötti. Ez Magyarország hévíztermelésének közel hatoda. Mivel a kutak többsége $60{ }^{\circ} \mathrm{C}$-nál melegebb vizet termel, ezért a kivett hömennyiség tekintetében még nagyobb szelet jut a megyére az ország geotermikusenergia-hasznosításából. A megye valamennyi városában müködik geotermikus fütési rendszer. A legjelentősebb Hódmezővásárhelyen, ahol a felszínre érkező $40-42{ }^{\circ} \mathrm{C}$ hőmérsékletü víz használati melegvízként, a $80-97^{\circ} \mathrm{C}$-os pedig távfütésre szolgál. A maximálisan kivett vízmennyiség kutanként legalább 20 liter/s. A jelenleg $10 \mathrm{MW}$ teljesítményü rendszert továbbra is folyamatosan fejlesztik. Az energetikailag hasznosított, lehült hévíz visszasajtolása is eredményesen folyik, ezzel a hévíztároló élettartama is megnövekszik. A megye kútállományát a 6. ábra szemlélteti, a megfelelő állapotban lévő és a szükséges átalakításokkal hévíztermelésre alkalmassá tehető meddő szénhidrogénkutakat pedig a 7. ábra mutatja.

Magyarország legjelentősebb hévízkészlete ugyan Békés és Csongrád megyében van, de a Bükk-hegység térségében jelentős mennyiségü, egységesnek tekinthető hideg-meleg karsztrendszer található (Lénárt, 2011). A hideg karsztvíz termelése 


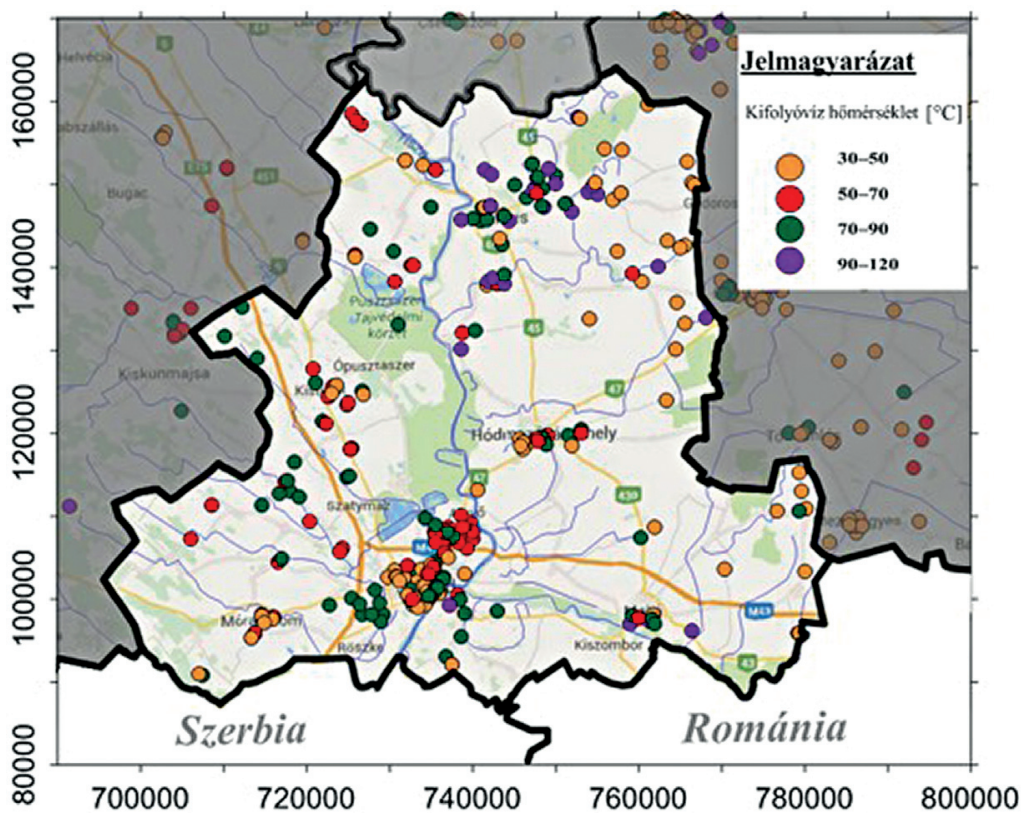

6. ábra. Csongrád megyei termálkutak (Tóth, 2016)

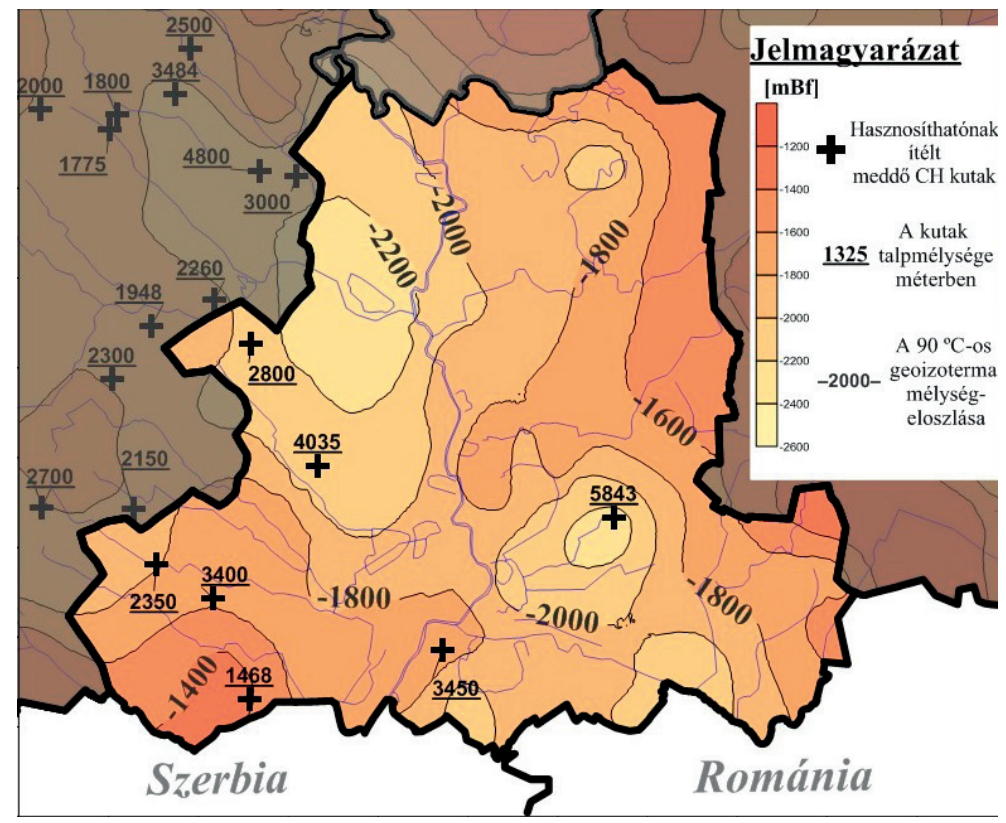

7. ábra. Csongrád megyei felhagyott szénhidrogénkutak (Tóth, 2016) 
csökkenő tendenciájú, ezzel szemben a meleg karsztvíz termelése 2001-től fokozatosan emelkedik. A fúrásokon át kiemelt karsztvíz hőmérséklete $40-95{ }^{\circ} \mathrm{C}$ között mozog, általában minél mélyebbről emelkedik a felszínre, annál melegebb.

Borsod-Abaúj-Zemplén megye hévízkataszteri számmal ellátott kútjainak száma ötvenegy. A megye húsz településén folyik hévíztermelés, melyek nagyobb számban balneológiai célt szolgálnak. A megye termálfürdőinek kútjait - Mezökövesd Zsóry (1939), Bogács (1955), Tiszaújváros (1976) - rendre olaj után kutatva találták meg, Miskolctapolca barlangfürdőjét kivéve.

Ugyanakkor Borsod-Abaúj-Zemplén megyében, Miskolcon található hazánk legjelentősebb termálvízalapú távfütési rendszere. A PannErgy Zrt. 2010-ben kezdődött első miskolci geotermikus projektje messze felülmúlta az előzetes várakozásokat. Így az első fúrásokat több kapcsolódó projekt is követte. A projektek során két termelö- és három visszasajtolókutat mélyítettek 2305-1514 m mélységben. A két termelökútból $6600-9000$ liter, $90-105{ }^{\circ} \mathrm{C}$ hőmérsékletü termálvizet termelnek ki. A Kistokaj térségéből kitermelt termálvizet mintegy 22 km hosszú, szigetelt távvezeték szállítja a Miskolc, Tatár utcai fütőmühöz 50-60 MW hőkapacitással.

A visszasajtolás hőmérséklete ugyanakkor igen magas, $57{ }^{\circ} \mathrm{C}$, ami további, ún. kaszkád felhasználást kívánna. Ez lehetne a kúthoz lehetőség szerint legközelebb telepített üvegházak fütése és/vagy a környező települések (Mályi, Kistokaj, Muhi, Emőd, Felsőzsolca) bekapcsolása a távhőszolgáltatásba. A kutakból 2015-től igen jelentős mennyiségü termálkarsztvizet termelnek ki, majd a lehült hévizet visszasajtolják. A térség meleg karsztvízkészletének pontos meghatározására, a tároló modellezésére, a visszasajtolás okozta hidegfront terjedésének vizsgálatára feltétlenül szükség lenne.

\section{ÖSSZEFOGLALÁS}

A geotermikus energia alkalmazása mellett számos nyomós érv szól. Ezek között első helyen kell, hogy szerepeljenek Magyarország kedvező természeti adottságai. A Kárpát-medence alatti elvékonyodott földkéreg és az arra települt rossz hővezető képességü üledéksorok együttesen eredményezik azt, hogy a köpenyből érkező fütés erőssége, a földi hőáram teljesítménysürüsége, valamint a mélységgel gyorsan növekvő kőzethőmérséklet (a geotermikus gradiens) egyaránt jelentôsen meghaladják az európai átlagot. Ebben a természeti környezetben három nagy, már ma is gazdaságosan kitermelhető készlettípus található. Az ún. felső-pannon homokos-homokköves porózus hévíztárolók, a triász korú repedezett-karsztosodott karbonátos tárolók, valamint a felszínhez közeli néhány száz méteres alacsony hőmérsékletủ zóna, amely hőcserélő kutakkal és hőszivattyúkkal müvelhető. Ezek együttes energiatartalma 454000 PJ, amelyből a kitermelési 
technológiától függően akár 115000 PJ is a felszínre hozható. Összességében tehát természeti adottságaink kedvezőek, s nemcsak a jelenben, de a távolabbi jövőben is adottak a hatékony geotermikusenergia-termelés feltételei.

Magyarország jelentős energiaimportra szorul. A geotermikus energiakincsünk többszörös jelentőséggel bír, egyrészt jelentősen csökkentheti importfüggőségünket, másrészt tiszta energia, nincs károsanyag-emisszió, ezáltal lassítani képes korunk egyik problémáját, a nemkívánatos klímaváltozást. Mindezek alapján megállapítható, hogy a geotermikus energia mint hazai, környezetbarát és gazdaságos energiaforrás alkalmas arra, hogy a magyar gazdaság egyik húzóereje lehessen. Bízunk benne, hogy a Magyar Energetikai és Közmü-szabályozási Hivatal kezdeményezésére 2016-ban készült Magyarország geotermikus atlasza hasznosnak bizonyul e cél elérése érdekében. Az eltelt időszakban a kiadvány iránt tapasztalt nagyfokú érdeklődés, többszöri utánnyomása is ezt a tény támasztja alá. A közeljövőben megjelenő Geotermikus Budapest könyvünkkel tovább kívánjuk szolgálni geotermikus energiakincsünk tudatos és következetes hasznosítását.

\section{IRODALOM}

Bobok E. - Tóth A. (2010): A geotermikus energia helyzete és perspektívái. Magyar Tudomány, 171, 8, 926-937. http://www.matud.iif.hu/2010/08/04.htm

Boldizsár T. (1958): The Distribution of Temperature in Flowing Wells. American Journal of Science, 256, 294-298. https://www.researchgate.net/publication/274820568_The_distribution of_temperature_in_flowing_wells

Boldizsár T. (1967): Terrestrial Heat and Geothermal Resources in Hungary. Bulletin Volcanologique, 30, 1, 221-227. https://www.researchgate.net/publication/248108328_Terrestrial_heat_ and_geothermal_resources_in_Hungary

Dövényi P. et al. (1983): Geothermal Conditions of Hungary. Geophysical Transactions, 29, 3-114. http://epa.oszk.hu/02900/02941/00055/pdf/EPA02941_geofizikai_kozlemenyek_1983_29_1_003-112.pdf

Dövényi P. et al. (2002): Atlas of Geothermal Resources in Europe. Official Publication of European Communities

Lénárt L. (2011): A bükki termálkarszt Egerszalók-Demjén-i része feltártsága. (A Miskolci Egyetem közleményei. A sorozat, Bányászat, 81. kötet) 17-25. http://midra.uni-miskolc.hu/document/12238/4303.pdf

Tóth A. (2015): Hungarian Country Update 2010-2014. Proceedings of the World Geothermal Congress 2015, Melbourne, https://pangea.stanford.edu/ERE/db/WGC/papers/WGC/2015/ 01024.pdf

Tóth A. (2016): Magyarország geotermikus felmérése 2016. Budapest: Magyar Energetikai és Közmú-szabályozási Hivatal kiadó (második kiadás)

Tóth A. (2017): Creating a Geothermal Atlas of Hungary. Proceedings of the $42^{\text {nd }}$ Workshop on Geothermal Reservoir Engineering, Stanford University, California, USA, SGP-TR-212, https:// pangea.stanford.edu/ERE/pdf/IGAstandard/SGW/2017/Toth.pdf 